\title{
MOTIVASI ANGGOTA KELOMPOK WANITA TANI DALAM DIVERSIFIKASI PANGAN LOKAL DI KABUPATEN BANTUL
}

\section{Motivation of Women Farmers Group in Diversification of Local Food in Bantul District}

\author{
Resti Kinanthi $^{1)}$, Subejo $^{2)}$, Roso Witjaksono ${ }^{2)}$ \\ 1) Jurusan Sosial Ekonomi Pertanian Fakultas Pertanian Universitas Gadjah Mada \\ ${ }^{2)}$ Fakultas Pertanian Universitas Gadjah Mada
}

\begin{abstract}
This research was done in Bantul district. The purposes of this research were to find out the motivation rate of women farmers group in diversification of local food in Bantul district, the influencing factors, and also to find out the influence of motivation and the other factors to successing local food diversification. This research bassicaly applied analytic descriptive method and used purposive method for sub-district and women farmers group sampling. It was took 15 group members from each women farmers group using simple random sampling, so in total there were 60 members as sample. Data analysis has been done by using propostion test and multiple regression analysis.

The research results showed that the larger part of women farmers group in Bantul district have a high motivation on the local food diversification, price of rice and active counseling have a possitive influence on motivation. Meanwhile, age, level of education, income, perception of local foods, and mass media access do not have influence to the motivation of local food diversivication. Price of rice has a negative influence on success local food diversification, while income, active counseling, perception of local foods have a possitive influence of local food diversification sucess. Meanwhile, age, level of education, mass media access and motivation do not have influence on local food diversification success.
\end{abstract}

Keywords : Motivation, Women Farmers Group, Diversified, Local Food, Bantul

\section{PENDAHULUAN}

Melihat fenomena konsumsi masyarakat indonesia di bidang pangan, maka budaya mengkonsumsi pangan impor seperti gandum dan beras impor perlu diperbaiki melalui berbagai program diversifikasi pangan. Hal ini menjadi hal yang menarik mengingat negara maju seperti Jepang pun sudah memilih untuk mengubah konsumsi pangannya dengan tidak lagi bergantung terhadap gandum dan daging, beralih ke pangan yang berbasis sumberdaya lokal. Oleh sebab itu, Indonesia sebagai negara berkembang dengan jumlah penduduk yang besar sudah sewajarnya memperhatikan pola konsumsi pangan masyarakatnya.

Dahulunya masyarakat Indonesia memiliki makanan pokok yang berbeda-beda di setiap daerah seperti sagu, ketela, jagung serta umbiumbian sesuai bahan pangan yang bisa dihasilkan di daerahnya sendiri. Keberhasilan revolusi hijau yang dimulai tahun 1950-an membawa peningkatan produksi padi yang diikuti dengan swasembada beras di Indonesia. Sejak saat itu makanan pokok penduduk Indonesia menjadi kurang beragam dimana konsumsi makanan pokok didominasi oleh beras. Hampir semua kalangan masyarakat mengkonsumsi beras sebagai makanan pokok, sehingga tingkat ketergantungan terhadap beras sangat tinggi. Konsumsi beras sebagai makanan pokok telah menjadi budaya bagi sebagian besar penduduk Indonesia dan mengurangi keberagaman konsumsi pangan pokok di Indonesia.

Selain itu, penjajahan yang dilakukan oleh negara Belanda dan Inggris membawa dampak pula bagi konsumsi masyarakat Indonesia. Mie dan roti menjadi makanan yang tidak dapat terpisahkan dari makanan sehari-hari, memperparah ketergantungan masyarakat indonesia terhadap gandum. Hal ini mendorong masyarakat dan pemerintah untuk melakukan diversifikasi pangan dengan menggunakan kembali bahan pangan lokal non-beras sebagai sumber karbohidrat dan protein yang baru untuk mengurangi konsumsi beras nasional melalui Model Pengembangan Pangan Pokok Lokal (MP3L). Model Pengembangan Pangan Pokok Lokal (MP3L) merupakan salah satu kegiatan pokok yang menjadi bagian dari gerakan Percepatan Penganekaragaman Konsumsi Pangan 
(P2KP) yang dilaksanakan oleh Kementerian Pertanian. Dalam Permentan No.15 tahun 2013 tujuan dari kegiatan MP3L adalah untuk mengembangkan pangan lokal sumber karbohidrat selain beras dan terigu yang secara khusus dipersiapkan untuk mendukung pelaksanaan program pangan bersubsidi bagi keluarga berpendapatan rendah. Pangan lokal dapat berupa umbi-umbian serta berbagai macam biji-bijian. Umbi-umbian yang dikembangkan antara lain ketela pohon, garut, gadung serta talas ada juga komoditas sampingan berupa produk olahan jagung, pisang serta bonggol pisang.

Selama ini pangan lokal seperti ketela pohon, ganyong, garut, dan umbi-umbian lain dianggap sebagai makanan kelas dua yang mempunyai rasa dan penampilan yang seadanya sehingga kurang menarik untuk dikonsumsi. Hal ini menjadi tantangan tersendiri bagi pemerintah yang sedang giat-giatnya menarik masyarakat untuk kembali mengkonsumsi pangan lokal.

Program pengembangan pangan lokal dikembangkan oleh 250 kabupaten di 12 provinsi di Indonesia. Kabupaten Bantul merupakan salah satu kabupaten di Indonesia yang mempunyai perhatian tinggi terhadap diversifikasi pangan lokal yang diwujudkan dalam pengembangan P2KP. Diversifikasi pangan lokal telah dilakukan di beberapa kecamatan antara lain kecamatan Sedayu, Pajangan, Srandakan, Imogiri dan Dlingo dan Pundong. Kebijakan tersebut dimaksudkan untuk menggerakkan kegiatan diversifikasi pangan lokal yang dilakukan melalui Kelompok Wanita Tani (KWT). Diversifikasi pangan lokal memerlukan dukungan berbagai pihak seperti pemerintah, penyuluh, Kelompok Wanita tani serta masyarakat yang saling bekerjasama melaksanakan fungsinya masingmasing untuk mencapai tujuan bersama.

Kelompok Wanita Tani (KWT) merupakan bagian yang mengambil peranan penting serta merupakan penggerak utama dalam diversifikasi pangan lokal. Wanita dalam hal ini bertugas sebagai pengolah dan penyedia bahan pangan bagi keluarganya, oleh karena itu Kelompok Wanita Tani banyak dilibatkan dalam kegiatan diversifikasi pangan lokal ini. Keberhasilan diversifikasi pangan lokal tercermin dalam perilaku anggota KWT mengkonsumsi pangan lokal dalam kehidupan sehari-hari yang tentunya tidak dapat terlepas dari motivasi masing-masing individu. Sejauh mana motivasi dapat mempengaruhi perilaku anggota KWT dalam diversifikasi pangan lokal menjadi hal yang menarik untuk dikaji. Tujuan dari penelitian ini adalah untuk mengetahui tingkat motivasi anggota KWT dalam diversifikasi pangan lokal, faktor-faktor yang mempengaruhinya, serta pengaruh motivasi dan faktor lain terhadap keberhasilan diversifikasi pangan lokal.

\section{METODE PENELITIAN}

Penelitian ini dilaksanakan pada tahun 2013 dengan lokasi penelitian di Kabupaten Bantul. Pemilihan sampel kecamatan dilakukan secara purposive dengan pertimbangan di kecamatan tersebut dikembangkan pangan lokal umbi-umbian dan jagung. Sampel Kelompok Wanita Tani dipilih berdasarkan KWT tersebut sudah melaksanakan program P2KP pada tahun 2012. Pemilihan sampel anggota KWT dipilih secara acak sebanyak 15 orang dari 4 KWT dengan total sampel 60 orang.

Metode penelitian yang digunakan adalah metode deskriptif dengan pendekatan kuantitatif menggunakan kuesioner. Data yang digunakan dalam penelitian ini adalah data primer dan data sekunder.

\section{HASIL PENELITIAN DAN PEMBAHASAN Keadaan umum daerah penelitian}

Kabupaten bantul merupakan salah satu wilayah di Provinsi Daerah Istimewa Yogyakarta yang terletak paling selatan. Secara geografis letak Kabupaten Bantul berada di antara $07^{\circ} 44^{\prime} 04^{\prime \prime}-08^{\circ} 00^{\prime 2} 27^{\prime \prime}$ Lintang Selatan dan $110^{\circ} 12 ' 34 "-110^{\circ} 31^{\prime} 08^{\prime \prime}$ Bujur Timur. Luas wilayah Kabupaten Bantul adalah 506,85 km² dan secara administratif terdiri dari 17 kecamatan yang dibagi menjadi 75 desa dan 933 pedukuhan. Secara umum iklim di wilayah Kabupaten Bantul dapat dikategorikan sebagai daerah beriklim tropis basah (humid tropical climate) karena termasuk tipe Af sampai Am dari klasifikasi iklim Koppen.

Penggunaan lahan terbesar di Kabupaten Bantul adalah sebagai kebun campuran sebesar $16.625,67$ ha atau $32,75 \%$ dari luas wilayah total 
di Kabupaten Bantul. Penggunaan lahan terbesar kedua yaitu sebagai lahan sawah seluas 15.879,4 ha atau 31,33\% dari total luas wilayah Kabupaten Bantul. Alokasi penggunaan lahan terkecil adalah sebagai tambak yaitu seluas 30 ha atau $0,06 \%$ dari luas wilayah Kabupaten Bantul.

Jumlah penduduk Kabupaten Bantul berdasarkan data monografi tahun 2012 sebanyak 930.276 jiwa dengan luas wilayah seluas 50.685 ha atau seluas $506,85 \mathrm{~km}^{2}$. Kepadatan penduduk di Kabupaten Bantul adalah $1.835 \mathrm{Jiwa} / \mathrm{km}^{2}$ yang berarti setiap $1 \mathrm{~km}^{2}$ luas wilayah ditempati oleh 1.835 jiwa. Berdasarkan kriteria yang dibuat pemerintah dalam UU Nomor 56/PRP/1960, kepadatan penduduk di Kabupaten Bantul termasuk dalam katagori sangat padat karena kepadatan penduduk $>401 \mathrm{Jiwa} / \mathrm{km}^{2}$. Nilai sex ratio Kabupaten Bantul sebesar 99,49\% menunjukkan bahwa jumlah penduduk perempuan dan laki-laki memiliki komposisi yang hampir seimbang, dengan kata lain setiap 100 penduduk perempuan ada sekitar 100 penduduk laki-laki. Tingkat pendidikaan penduduk di Kabupaten Bantul paling banyak berada pada kelompok pendidikan SLTA yaitu sebanyak 29\% sehingga dapat dikatakan bahwa penduduk Kabupaten Bantul mempunyai tingkat pendidikan yang tinggi. Nilai Burden Dependence Ratio (BDR) sebesar 46,67\%, artinya setiap 100 penduduk produktif menanggung 47 penduduk tidak produktif dan belum produktif. Semakin tinggi nilai BDR menunjukkan tingkat beban ketergantungan semakin tinggi. Mata pencaharian penduduk di Kabupaten Bantul sebanyak 25\% didominasi oleh sektor pertanian. Terbesar kedua adalah penduduk yang bekerja di sektor perdagangan yaitu sebesar $21,16 \%$ dan yang paling kecil adalah pada sektor listrik, gas dan air sebesar $0,07 \%$. Sektor pertanian menjadi sektor yang paling banyak dijadikan pekerjaan utama di Kabupaten Bantul karena mengingat wilayah Kabupaten Bantul yang merupakan pedesaan dan memiliki lahan pertanian yang luas.

\section{Karakteristik Anggota Kelompok Wanita Tani}

Umur anggota KWT 35\% berada pada kisaran usia muda ( $\leq 40$ tahun), $65 \%$ lainnya dikatagorikan dalam usia tua (>40 tahun). Umur termuda anggota KWT yaitu 22 tahun dan umur tertuanya 62 tahun. Sedangkan rerata umur anggota KWT adalah 44,73 tahun.

Sebanyak 28 anggota KWT atau 46,67\% dari anggota mengenyam pendidikan SMP (7-9) tahun, terbanyak kedua yaitu berpendidikan SD (0-6 tahun) sebanyak 16 anggota atau 26,67\% . Dari seluruh responden anggota KWT hanya 16 orang yang mengenyam pendidikan SMA(9-12 tahun). Pendidikan tertinggi anggota KWT yaitu selama 12 tahun atau kelas 3 SMA. Pendidikan terendah anggota KWT yaitu pada tingkat kelas 2 SD. Rerata pendidikan anggota KWT di Kabupaten Bantul yaitu 8,7 tahun atau setara dengan kelas 3 SMP.

Sebanyak 48 orang atau $80 \%$ dari responden anggota KWT berpendapatan $<1.000 .000$, 9 orang atau $15 \%$ berpendapatan 1.000.000-2.000.000 dan 5 orang atau 5\% berpendapatan $>3.000 .000$.

Tingkat persepsi anggota KWT memiliki persentase yang tergolong tinggi yaitu sebesar $75,51 \%$. Skor tersebut merupakan rerata dari tiga aspek yaitu anggota KWT sebagai produsen pangan lokal, pengolah pangan lokal serta konsumen pangan lokal. Tingkat Persepsi anggota KWT sebagai produsen pangan lokal memiliki persentase $78,71 \%$. Dari aspek anggota KWT sebagai pengolah pangan lokal memiliki persentase tingkat persepsi sebesar 67,59\%. Selanjutnya yaitu dari aspek anggota KWT sebagai konsumen pangan lokal, tingkat persepsi mereka cukup tinggi yaitu sebesar 80,22\%. Konsumen pangan lokal merasa bahwa kandungan serat pangan lokal tinggi, mudah mendapatkan pangan lokal dan olahannya, serta cocok untuk disajikan dalam acara rapat/arisan/hajatan. Sebaran persepsi anggota KWT terhadap pangan lokal mayoritas pada katagori baik yaitu sebesar $71,67 \%$, sedangkan pada katagori sedang sebesar $28,33 \%$. Hal ini menunjukkan bahwa angota KWT merasa bahwa komoditas pangan lokal memiliki prospek yang baik untuk dikembangkan.

Keaktifan penyuluhan anggota KWT dengan katagori rendah yaitu dengan persentase $68,33 \%$, katagori sedang sebesar $18,33 \%$ dan katagori tinggi sebesar $13,33 \%$. Sebagian besar 
anggota KWT memiliki keaktifan yang rendah dalam penyuluhan dikarenakan mereka mengikuti penyuluhan secara pasif, enggan untuk bertanya serta mengemukakan pendapatnya.

Berdasarkan harga beras yang dikonsumsi, dapat diketahui bahwa sebesar $66,67 \%$ anggota KWT mengkonsumsi beras dengan harga yang tinggi yaitu seharga Rp.8300-8500/kg, sedangkan 33,33\% dari anggota KWT mengkonsumsi harga beras yang rendah (Rp.8000-8250/kg).

Rerata tingkat akses media massa anggota KWT sebesar $29,33 \%$. Media massa yang paling mudah untuk diakses oleh anggota KWT adalah media televisi yaitu dengan persentase 55\%, terbesar kedua adalah media koran/majalah sebesar $31,17 \%$, radio sebesar $24 \%$ serta paling rendah adalah media internet sebesar 7,22\% Media televisi menjadi media yang paling banyak diakses oleh anggota KWT karena media televisi merupakan media yang umum untuk dimiliki oleh semua anggota KWT. Sedangkan untuk media internet merupakan media yang paling jarang diakses oleh anggota KWT karena anggota KWT bermukim di pedesaan sehingga mereka kurang mengenal teknologi internet. Berdasarkan tingkat akses media massa anggota KWT mayoritas (60\%) tergolong rendah, 38,33\% tergolong sedang dan $1,67 \%$ tergolong tinggi.

Sebanyak $86,67 \%$ responden atau sebanyak 52 orang memiliki luas lahan dengan katagori sempit $\left(<2000 \mathrm{~m}^{2}\right)$, sedangkan 8 responden lainnya memiliki luas lahan dengan katagori luas $\left(>2000 \mathrm{~m}^{2}\right)$. Dari data tersebut dapat kita ketahui bahwa sebagian besar anggota KWT memiliki kemampuan produksi beras yang terbatas karena luas lahan yang mereka miliki sempit, sehingga untuk mencukupi kebutuhan konsumsi beras dalam satu tahun maka anggota KWT harus membeli beras saat stok yang mereka miliki telah habis dijual dan dikonsumsi sendiri.

\section{Motivasi Anggota KWT dalam Diversifikasi Pangan Lokal di Kabupaten Bantul}

Dari penelitian yang dilakukan, didapatkan hasil bahwa sebanyak 59 anggota KWT atau sebesar 98,33\% dari anggota KWT memiliki motivasi yang tergolong tinggi dengan total skor diatas 66 dari skor maksimal 130. Sisanya, 1 orang memiliki tingkat motivasi rendah dengan total skor $>65$. Hal ini menandakan bahwa secara umum anggota KWT dalam diversifikasi pangan lokal di Kabupaten Bantul memiliki motivasi yang tinggi.

Hipotesis pertama pada penelitian ini adalah diduga sebagian besar anggota KWT di Kabupaten Bantul memiliki motivasi yang tinggi $(>50 \%)$ dalam diversifikasi pangan lokal. Untuk membuktikan hipotesis pertama maka dilakukan uju proporsi sebagai berikut :

$$
\text { Zhit }=\frac{x / n-P o}{\sqrt{\frac{P o(1-P o)}{N}}}
$$

Keterangan :

$\mathrm{Z} \quad=$ statistik uji $\mathrm{Z}$ (distribusi normal)

$\mathrm{x} \quad=$ jumlah sampel anggota KWT yang memiliki motivasi yang tinggi

$\mathrm{n} \quad=$ jumlah keseluruhan responden anggota KWT

Po $=50 \%$

Hipotesis :

Ho : $\mathrm{P}<50 \%$

$\mathrm{Ha}: \mathrm{P} \geq 50 \%$

Dengan :

Ho : Diduga sebagian kecil $(<50 \%)$ anggota kelompok wanita tani memiliki motivasi yang tinggi dalam diversifikasi pangan lokal di Kabupaten Bantul.

Ha : Diduga sebagian besar ( $\geq 50 \%)$ anggota kerlompok wanita tani memiliki motivasi yang tinggi dalam diversifikasi pangan lokal di Kabupaten Bantul.

a. Tingkat signifikansi 0,05 (5\%)

b. Statistik Pengujian

$$
\begin{aligned}
\text { Zhit } & =\frac{x / n-P o}{\sqrt{\frac{P o(1-P o)}{N}}} \\
\text { Zhit } & =\frac{59 / 60-0.5}{\sqrt{\frac{0.5(1-0.5)}{60}}} \\
& =7,49
\end{aligned}
$$

$\mathrm{Z}$ tabel $=-1,645$

c. Kriteria Pengujian

Zhit $\mathrm{Z}$ tabel : Ho diterima, Ha ditolak Zhit $>$ Z tabel : Ho ditolak, Ha diterima 
d. Kesimpulan :

Ho ditolak, Ha diterima : sebagian besar $(\geq 50 \%)$ anggota kerlompok wanita tani memiliki motivasi yang tinggi dalam diversifikasi pangan lokal di Kabupaten Bantul.

Berdasarkan hasil perhitungan menggunakan uji proporsi, didapatkan hasil bahwa $\mathrm{Z}$ hitung sebesar 7,49 sedangkan $\mathrm{Z}$ tabel 1,645 sehingga Ha diterima. Hal ini berarti sebagian besar anggota KWT memiliki motivasi yang tinggi dalam diversifikasi pangan lokal di Kabupaten Bantul.

\section{Faktor-Faktor yang Mempengaruhi Motvasi Anggota KWT Diversifikasi Pangan Lokal di Kabupaten Bantul}

Motivasi anggota KWT dalam diversifikasi pangan lokal di Kabupaten Bantul diduga dipengaruhi oleh beberapa faktor, antara lain : umur, pendapatan, tingkat pendidikan, persepsi terhadap pangan lokal, keaktifan dalam penyuluhan, akses media massa serta harga beras. Untuk mengetahui faktor yang berpengaruh nyata terhadap motivasi digunakan analisis regresi berganda dengan metode backward menggunaakan SPSS 17.00. Pada tahap awal ditampilkan hasil dari semua variabel independent kemudian secara bertahap variabel independent yang tidak berpengaruh secara nyata terhadap variabel dependent akan dihilangkan.

Tabel 1. Hasil Analisis Regresi Faktor-Faktor yang diduga Mempengaruhi Motivasi Anggota KWT

\begin{tabular}{|l|r|c|r|}
\hline \multicolumn{1}{|c|}{ Variabel } & $\begin{array}{c}\text { Koefisien } \\
\text { Regresi }\end{array}$ & T hit & \multicolumn{1}{c|}{ Sig. } \\
\hline Harga beras & 0,034 & 3,296 & $0.02^{*}$ \\
\hline $\begin{array}{l}\text { Keaktifan } \\
\text { Penyuluhan }\end{array}$ & 0,955 & 1,763 & $0,083^{*}$ \\
\hline Konstanta & 186,619 & & 0,035 \\
\hline R Square & 0,203 & & \\
\hline Ajusted R Square & 0,175 & & \\
\hline F hitung & 7,275 & & \\
\hline
\end{tabular}

Ket : *) signifikansi $\alpha=10 \%$ ns : Non signifikansi $\alpha=10 \%$

Sumber: Analisis Data Primer, 2013

Berdasarkan pengujian analisis regresi berganda, variabel dependent adalah motivasi (Y) dan variabel independent (X) meliputi faktor umur, pendapatan, tingkat pendidikan, persepsi terhadap pangan lokal, keaktifan dalam penyuluhan, akses media massa serta harga beras. Hasil regresi berganda faktor-faktor yang mempengaruhi motivasi anggota KWT dalam diversifikasi pangan lokal di Kabupaten Bantul dapat dilihat pada tabel 1 .

Berdasarkan hasil analisis regresi linear berganda diatas, maka dapat disusun persamaan regresi sebagai berikut :

$$
\mathrm{Y}=-186,619+0,034+0,955
$$

Keterangan :

$\mathrm{Y}=$ Motivasi anggota KWT

$\mathrm{X}_{1}=$ Harga Beras

$\mathrm{X}_{2}=$ Keaktifan Penyuluhan

Dari persamaan regresi berganda diatas dapat dijelaskan sebagai berikut :

a. Nilai adjusted $R$ square (koefisien determinasi) merupakan salah satu kriteria penentu apakah suatu persamaan regresi tepat atau tidak. Nilai adjusted $\mathrm{R}$ square berada pada kisaran 0-1, yang berarti semakin mendekati angka 1 maka model regresi tersebut semakin tepat. Berdasarkan tabel 6.4 diketahui nilai adjusted $R$ square sebesar 0,175 menunjukkan bahwa $17,5 \%$ variabel motivasi dapat dijelaskan oleh variabel harga beras dan keaktifan penyuluhan sedangkan $82,5 \%$ dijelaskan oleh variabel lain diluar model.

b. Nilai $F$ adalah perbandingan antara rerata kuadrat dari regresi dengan rerata kuadrat residu. Berdasarkan analisis yang dilakukan, nilai $\mathrm{F}$ hitung adalah 7,275 dan $\mathrm{F}$ tabel 2,40. F hitung > F tabel menunjukkan bahwa variabel independent harga beras dan keaktifan penyuluhan secara bersama-sama berpengaruh nyata terhadap motivasi anggota KWT.

Berikut ini akan dibahas hasil uji hipotesis masing-masing faktor yang berpengaruh nyata terhadap motivasi yang merupakan hasil analisis regresi berganda (model 6).

\section{Harga Beras}

Pada tabel 1 dapat dilihat koefisien regresi variabel harga beras yaitu sebesar 0,034 dengan nilai signifikansi 0,02 lebih kecil dari taraf signifikansi $\alpha=10 \%$, T hitung 3,296 sedangkan $\mathrm{t}$ tabel 1,296. $\mathrm{T}$ hitung $>\mathrm{T}$ tabel sehingga hipotesis $3 c$ diterima. Variabel harga beras berpengaruh 
nyata terhadap motivasi anggota KWT dalam diversifikasi pangan lokal di Kabupaten Bantul, semakin tinggi harga beras yang dikonsumsi maka semakin tinggi motivasinya dalam diversifikasi pangan lokal. Berdasarkan hasil analisis regresi linear berganda, diperoleh persamaan regresi sebagai berikut :

$$
\mathrm{Y}=-186,619+0,034
$$

Keterangan :

$\mathrm{Y}=$ Motivasi anggota KWT

$\mathrm{X}_{1}=$ Harga Beras

Persamaan di atas disajikan dalam bentuk gambar 1 .

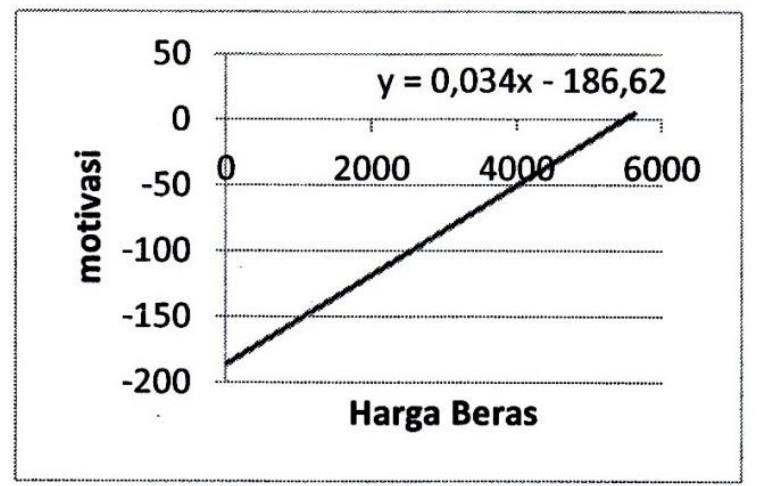

Gambar 1. Grafik Pengaruh Harga Beras terhadap Motivasi

Dari gambar 1 dapat diketahui bahwa koefisien variabel harga beras berpengaruh positif terhadap motivasi anggota KWT dalam diversifikasi pangan lokal. Tanda positif pada koefisien regresi menunjukkan bahwa hubungan antara variabel harga beras dan motivasi adalah searah. Berdasarkan persamaan regresi nilai konstanta sebesar -186,619. Apabila tidak ada pengaruh dari variabel harga beras $(=0)$ maka nilai motivasi sebesar $-186,619$. Nilai koefisien regresi 0,034 menunjukkan bahwa tiap penambahan satu nilai variabel harga beras() maka nilai motivasi (Y) akan bertambah sebesar 0,034. Dengan demikian hipotesis $3 \mathrm{c}$ diterima, semakin tinggi harga beras yang dikonsumsi maka motivasinya dalam diversifikasi pangan lokal juga semakin tinggi.

\section{Keaktifan Penyuluhan}

Pada tabel 2 dapat dilihat koefisien regresi variabel keaktifan penyuluhan yaitu sebesar 0,955 dengan nilai signifikansi 0,0083 lebih kecil dari taraf signifikansi $\alpha=10 \%$, T hitung 1,763 sedangkan $\mathrm{T}$ tabel 1,296. $\mathrm{T}$ hitung $>\mathrm{T}$ tabel, sehingga hipotesis $3 \mathrm{~b}$ diterima. Variabel keaktifan penyuluhan berpengaruh nyata terhadap motivasi anggota KWT dalam diversifikasi pangan lokal di Kabupaten Bantul, semakin tinggi keaktifan penyuluhan maka semakin tinggi motivasinya dalam diversifikasi pangan lokal. Berdasarkan hasil analisis regresi linear berganda, diperoleh persamaan regresi sebagai berikut :

$$
\mathrm{Y}=-186,619+0,955
$$

Keterangan :

$\mathrm{Y}=$ Motivasi anggota KWT

$\mathrm{X}_{1}=$ Keaktifan penyuluhan

Persamaan di atas disajikan dalam bentuk gambar 2.

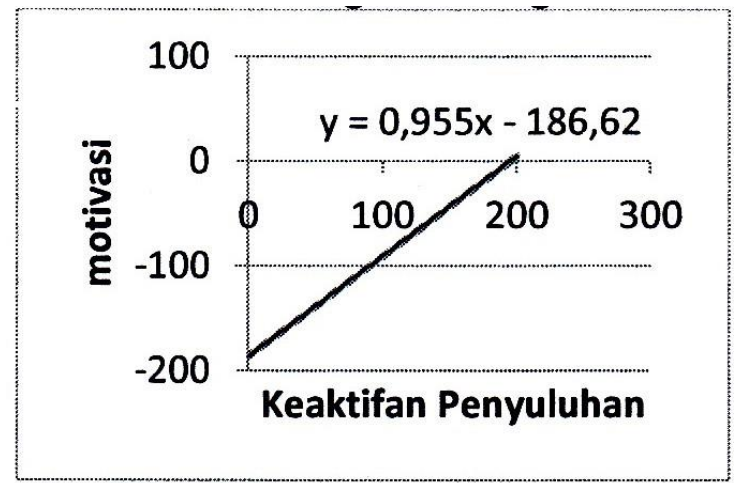

Gambar 2. Grafik Pengaruh Keaktifan

Penyuluhan terhadap Motivasi

Dari gambar 6.2 dapat diketahui bahwa koefisien variabel keaktifan penyuluhan berpengaruh positif terhadap motivasi anggota KWT dalam diversifikasi pangan lokal. Tanda positif pada koefisien regresi menunjukkan bahwa hubungan antara variabel keaktifan penyuluhan dan motivasi adalah searah. Berdasarkan persamaan regresi nilai konstanta sebesar -186,619. Apabila tidak ada pengaruh dari variabel keaktifan penyuluhan $(=0)$ maka nilai motivasi sebesar $-186,619$. Nilai koefisien regresi 0,034 menunjukkan bahwa tiap penambahan satu nilai variabel keaktifan penyuluhan () maka nilai motivasi (Y) akan bertambah sebesar 0,955. Dengan demikian hipotesis $3 \mathrm{~b}$ diterima, semakin tinggi keaktifan penyuluhan maka semakin tinggi motivasinya dalam diversifikasi pangan lokal. 


\section{Motivasi dan Faktor Lain yang Diduga Mempengaruhi Keberhasilan Diversifikasi Pangan Lokal}

Dari penelitian yang dilakukan dapat diketahui bahwa 39 anggota KWT atau sebesar 65\% memiliki tingkat keberhasilan katagori sedang dalam diversifikasi pangan lokal. Sedangkan sebanyak 21,67\% anggota KWT memiliki tingkat keberhasilan diversifikasi pangan lokal yang tinggi dan 13,33\% lainnya memiliki tingkat keberhasilan diversifikasi pangan lokal yang rendah.

Tujuan ketiga dari penelitian ini adalah untuk mengetahui pengaruh motivasi dan faktor lain yang berpengaruh terhadap keberhasilan diversifikasi pangan lokal di Kabupaten Bantul. Dalam menguji hipotesis ketiga maka digunakan analisis regresi linear berganda dengan menggunakan SPSS 16.0. Variabel dependent (Y) adalah keberhasilan diversifikasi pangan lokal di Kabupaten Bantul sedangkan variabel dependent (X) adalah motivasi, umur, pendidikan, pendapatan, harga beras, keaktifan penyuluhan, persepsi, akses media massa dan persepsi terhadap pangan lokal.

Tabel 2. Hasil Analisis Regresi Linier Berganda Mengenai Faktor-Faktor yang Diduga Mempengaruhi Keberhasilan Diversifikasi Pangan Lokal di Kabupaten Bantul

\begin{tabular}{|l|r|r|r|}
\hline \multicolumn{1}{|c|}{ Variabel } & $\begin{array}{c}\text { Koefisien } \\
\text { Regresi }\end{array}$ & \multicolumn{1}{c|}{ T hit } & \multicolumn{1}{c|}{ Sig. } \\
\hline Pendapatan & 2,538 & 2,171 & $0.034^{*}$ \\
\hline Harga beras & $-0,009$ & $-2,239$ & $0,029^{*}$ \\
\hline $\begin{array}{l}\text { Keaktifan } \\
\text { Penyuluhan }\end{array}$ & 1,129 & 4,264 & $0,000^{*}$ \\
\hline Persepsi & 0,518 & 4,962 & $0,000^{*}$ \\
\hline Konstanta & 73,829 & & 0,045 \\
\hline R Square & 0,643 & & \\
\hline Ajusted R Square & 0,617 & & \\
\hline F hitung & 24,773 & & \\
\hline
\end{tabular}

Ket : *) signifikansi $\alpha=10 \%$ ns : Non signifikansi $\alpha=10 \%$

Sumber: Analisis Data Primer, 2013

Berdasarkan hasil analisis regresi linear berganda diatas, maka dapat disusun persamaan regresi sebagai berikut :

$$
Y=73,829+2,538+-0,009+1,129+0,518
$$

Keterangan :

$$
\mathrm{Y}=\text { Keberhasilan Diversifikasi Pangan Lokal }
$$

$\mathrm{X}_{1}=$ Pendapatan

$\mathrm{X}_{2}=$ Harga Beras

$\mathrm{X}_{3}=$ Keaktifan Penyuluhan

$\mathrm{X}_{4}=$ Persepsi

Dari persamaan regresi berganda di atas dapat dijelaskan sebagai berikut :

a. Nilai adjusted $R$ square (koefisien determinasi) merupakan salah satu kriteria penentu apakah suatu persamaan regresi tepat atau tidak. Nilai adjusted $\mathrm{R}$ square berada pada kisaran 0-1, yang berarti semakin mendekati angka 1 maka model regresi tersebut semakin tepat. Berdasarkan tabel 2 diketahui nilai adjusted $R$ square sebesar 0,643 menunjukkan bahwa $64,3 \%$ variabel motivasi dapat dijelaskan oleh variabel pendapatan, harga beras, keaktifan penyuluhan dan persepsi sedangkan 35,7\% dijelaskan oleh variabel lain diluar model.

b. Nilai $F$ adalah perbandingan antara rerata kuadrat dari regresi dengan rerata kuadrat residu. Berdasarkan analisis yang dilakukan, nilai $\mathrm{F}$ hitung adalah 24,773 dan $\mathrm{F}$ tabel 2,05. $\mathrm{F}$ hitung > F tabel menunjukkan bahwa variabel independent pendapatan, harga beras, keaktifan penyuluhan dan persepsi secara bersama-sama berpengaruh nyata terhadap keberhasilan diversifikasi pangan lokal di Kabupaten Bantul.

Berikut ini akan dibahas hasil uji hipotesis masing-masing faktor yang berpengaruh nyata terhadap keberhasilan diversifikasi pangan lokal di Kabupaten Bantul yang merupakan hasil analisis regresi berganda (model 5).

\section{Pendapatan}

Koefisien regresi untuk variabel pendapatan yaitu sebesar 2,538 dengan nilai signifikansi 0,034. Nilai signifikansi variabel pendapatan lebih kecil daripada taraf signifikansi $\alpha=10 \%$, T hitung 2,171 sedangkan $\mathrm{T}$ tabel 1,297. $\mathrm{T}$ hitung $>\mathrm{T}$ tabel sehingga variabel pendapatan berpengaruh nyata terhadap keberhasilan diversifikasi pangan lokal di Kabupaten Bantul. Dengan demikian dapat disimpulkan bahwa hipotesis $4 \mathrm{~b}$ diterima, pendapatan berpengaruh nyata terhadap keberhasilan diversifikasi pangan lokal di Kabupaten Bantul. Berdasarkan hasil 
analisis regresi linear berganda, diperoleh persamaan regresi sebagai berikut :

$$
\mathrm{Y}=73,829+2,538
$$

Keterangan :

$\mathrm{Y}=$ Keberhasilan diversifikasi pangan lokal

$\mathrm{X}_{1}=$ Pendapatan

Persamaan di atas disajikan dalam bentuk gambar 3.

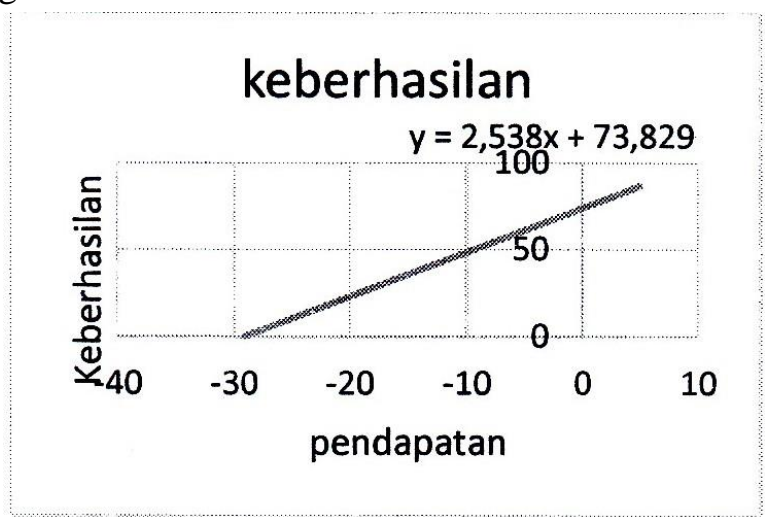

Gambar 3. Pengaruh Variabel Pendapatan terhadap Keberhasilan Diversifikasi Pangan Lokal

Dari gambar 3, dapat diketahui bahwa koefisien variabel pendapatan berpengaruh positif terhadap keberhasilan diversifikasi pangan lokal. Tanda positif pada koefisien regresi menunjukkan bahwa hubungan antara variabel pendapatan dan keberhasilan diversifikasi pangan lokal adalah searah. Berdasarkan persamaan regresi nilai konstanta sebesar 73,829. Apabila tidak ada pengaruh dari variabel pendapatan $(=0)$ maka nilai keberhasilan diversifikasi sebesar 73,829. Nilai koefisien regresi 0,518 menunjukkan bahwa tiap penambahan satu nilai variabel pendapatan () maka nilai keberhasilan diversifikasi (Y) akan bertambah sebesar 0,518. Dengan demikian dapat disimpulkan bahwa hipotesis $4 \mathrm{~b}$ diterima, semakin tinggi pendapatan maka keberhasilan diversifikasi pangan lokal juga semakin tinggi.

\section{Harga Beras}

Pada tabel 3, dapat dilihat koefisien regresi variabel harga beras yaitu sebesar - 0,009 dengan nilai signifikansi 0,029 lebih kecil dari taraf signifikansi $\alpha=10 \%$, T hitung $-2,239$ sedangkan $\mathrm{T}$ tabel 1,297 . $\mathrm{T}$ hitung $>\mathrm{T}$ tabel sehingga hipotesis $4 \mathrm{c}$ diterima, variabel harga beras berpengaruh nyata terhadap keberhasilan diversifikasi pangan lokal di Kabupaten Bantul. Berdasarkan hasil analisis regresi linear berganda, diperoleh persamaan regresi sebagai berikut :

$$
\mathrm{Y}=73,829-0,009
$$

Keterangan :

$\mathrm{Y}=$ Keberhasilan diversifikasi pangan lokal $\mathrm{X}_{2}=$ Harga Beras

Persamaan di atas disajikan dalam bentuk gambar 4.

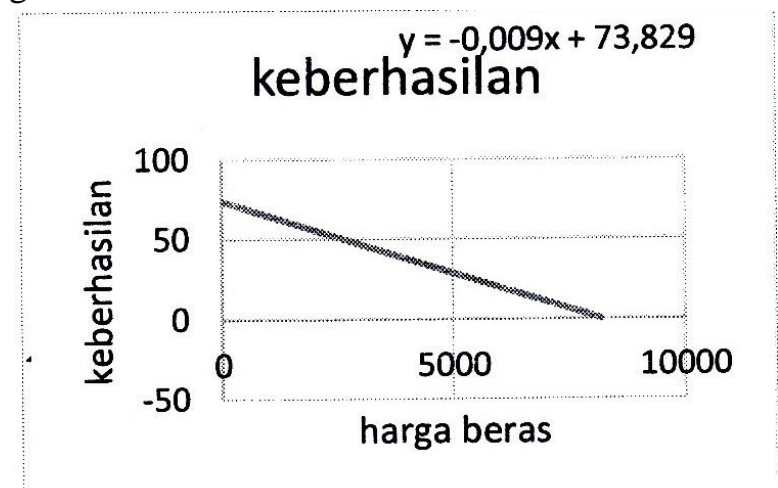

Gambar 4. Pengaruh Variabel Harga Beras Terhadap Keberhasilan Diversifikasi Pangan Lokal

Dari gambar 4, dapat diketahui bahwa koefisien variabel harga beras berpengaruh negatif terhadap keberhasilan diversifikasi pangan lokal. Tanda negatif pada koefisien regresi menunjukkan bahwa hubungan antara variabel harga beras dan keberhasilan diversifikasi adalah berkebalikan. Berdasarkan persamaan regresi nilai konstanta sebesar 73,829. Apabila tidak ada pengaruh dari variabel harga beras $(=0)$ maka nilai keberhasilan diversifikasi sebesar 73,829. Nilai koefisien regresi- 0,009 menunjukkan bahwa tiap penambahan satu nilai variabel pendapatan () maka nilai keberhasilan diversifikasi (Y) akan berkurang sebesar 0,009. Dengan demikian hipotesis $4 \mathrm{c}$ diterima, semakin rendah harga beras yang dikonsumsi maka semakin tinggi keberhasilan diversifikasi pangan lokal.

\section{Keaktifan Penyuluhan}

Pada tabel 3 dapat dilihat koefisien regresi variabel keaktifan penyuluhan yaitu sebesar 1,129 dengan nilai signifikansi 0,000 lebih kecil dari taraf signifikansi $\alpha=10 \%$, nilai $\mathrm{T}$ hitung 4,264 sedangkan $\mathrm{T}$ tabel 1,297. $\mathrm{T}$ hitung $>\mathrm{T}$ tabel 
sehingga hipotesis $4 \mathrm{~b}$ diterima, variabel keaktifan penyuluhan berpengaruh nyata terhadap keberhasilan diversifikasi pangan lokal di Kabupaten Bantul. Dari hasil analisis regresi linear berganda didapatkan persamaan sebagai berikut :

$$
\mathrm{Y}=73,829+1,129
$$

Keterangan :

$\mathrm{Y}=$ Keberhasilan diversifikasi pangan lokal

$\mathrm{X}_{3}=$ Keaktifan Penyuluhan

Persamaan di atas disajikan dalam bentuk gambar 5.

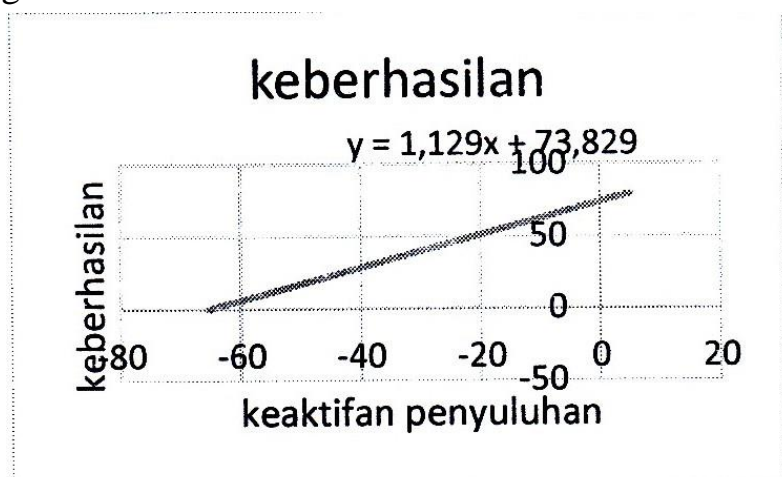

Gambar 5. Pengaruh Variabel Keaktifan

Penyuluhan Terhadap Keberhasilan Diversifikasi Pangan Lokal

Dari gambar 5, dapat diketahui bahwa koefisien variabel keaktifan penyuluhan berpengaruh positif terhadap keberhasilan diversifikasi pangan lokal. Tanda positif pada koefisien regresi menunjukkan bahwa hubungan antara variabel keaktifan penyuluhan dan keberhasilan diversifikasi pangan lokal adalah searah. Berdasarkan persamaan regresi nilai konstanta sebesar 73,829. Apabila tidak ada pengaruh dari variabel keaktifan penyuluhan $(=0)$ maka nilai keberhasilan diversifikasi sebesar 73,829. Nilai koefisien regresi 1,129 menunjukkan bahwa tiap penambahan satu nilai variabel keaktifan penyuluhan () maka nilai keberhasilan diversifikasi (Y) akan bertambah sebesar 1,129. Dengan demikian hipotesis $4 \mathrm{~b}$ diterima, Semakin tinggi keaktifan penyuluhan maka semakin tinggi keberhasilan diversifikasi pangan lokal.

\section{Persepsi Terhadap Pangan Lokal}

Koefisien regresi untuk variabel persepsi terhadap pangan lokal yaitu sebesar 0,456 dengan nilai signifikansi 0,000 . Nilai signifikansi variabel persepsi terhadap pangan lokal lebih kecil daripada taraf signifikansi $\alpha=10 \%$, nilai $\mathrm{T}$ hitung 4,962 sedangkan $\mathrm{T}$ tabel 1,297. T hitung> $\mathrm{T}$ tabel sehingga variabel persepsi terhadap pangan lokal berpengaruh nyata terhadap keberhasilan diversifikasi pangan lokal di Kabupaten Bantul. Dengan demikian dapat disimpulkan bahwa hipotesis 4d diterima, persepsi terhadap pangan lokal berpengaruh nyata terhadap keberhasilan diversifikasi pangan lokal di Kabupaten Bantul. Semakin baik persepsi terhadap pangan lokal maka keberhasilan diversifikasi pangan lokal juga semakin tinggi.

Berdasarkan hasil analisis regresi linear berganda, diperoleh persamaan regresi sebagai berikut :

$$
\mathrm{Y}=73,829+0,518
$$

Keterangan :

$\mathrm{Y}=$ Keberhasilan diversifikasi pangan lokal

$\mathrm{X}_{4}=$ Persepsi terhadap pangan lokal

Persamaan di atas disajikan dalam bentuk gambar 6.

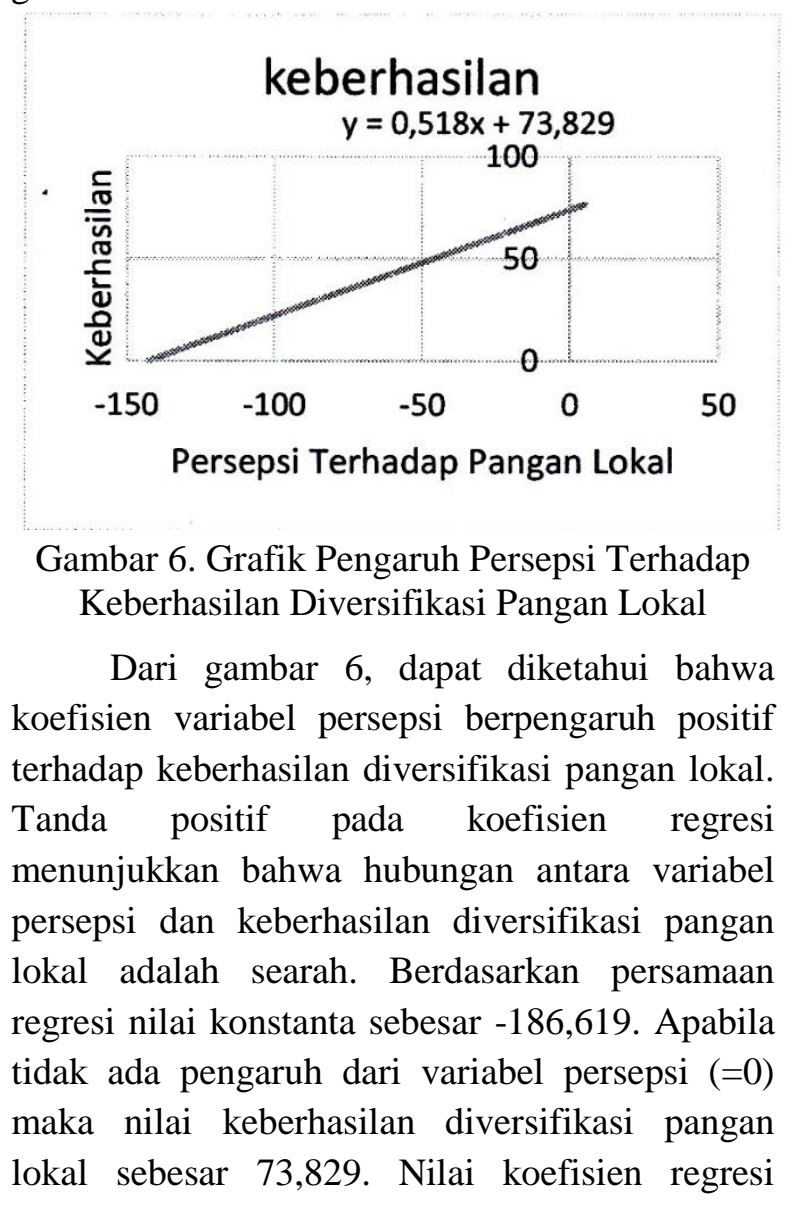


0,518 menunjukkan bahwa tiap penambahan satu nilai variabel persepsi () maka nilai keberhasilan diversifikasi pangan lokal (Y) akan bertambah sebesar 0,518. Dengan demikian, dapat disimpulkan bahwa hipotesis $4 \mathrm{~d}$ diterima, semakin tinggi persepsi terhadap pangan lokal maka semakin tinggi keberhasilan diversifikasi pangan lokal.

\section{KESIMPULAN DAN SARAN}

\section{Kesimpulan}

1. Motivasi anggota KWT dalam diversifikasi pangan lokal di Kabupaten Bantul secara umum termasuk tinggi dengan sebaran motivasi katagori tinggi sebanyak 83,33\%. Ragam kebutuhan yang ingin dipenuhi yaitu Existence dengan tingkat motivasi $78,99 \%$, Relatedness dengan tingkat motivasi $79,96 \%$ dan Growth dengan tingkat motivasi $81,94 \%$.

2. Ragam motivasi yang paling ingin dipenuhi anggota KWT dalam diversifikasi pangan lokal adalah komponen Growth, mereka sangat ingin untuk memenuhi kebutuhan untuk berkembang seperti menigkatkan pengetahuan, mengembangkan kreativitas, memperoleh pengalaman serta mengembangkan skala usaha yang telah ada.

3. Faktor-faktor yang berpengaruh secara signifikan terhadap motivasi anggota KWT dalam diversifikasi pangan lokal yaitu faktor harga beras dan faktor keaktifan penyuluhan. Semakin tinggi harga beras maka motivasi anggota KWT semakin tinggi. Semakin aktif anggota KWT dalam penyuluhan maka motivasinya juga akan semakin tinggi. Faktor yang tidak berpengaruh adalah faktor umur, tingkat pendidikan, persepsi terhadap pangan lokal, pendapatan, dan akses media massa.

4. Faktor-faktor yang berpengaruh secara signifikan terhadap keberhasilan diversifikasi pangan lokal adalah pendapatan, keaktifan dalam penyuluhan, harga beras dan persepsi terhadap pangan lokal. Semakin tinggi pendapatan anggota KWT maka keberhasilan diversifikasi pangan lokal juga semakin tinggi. Semakin aktif anggota KWT dalam penyuluhan maka keberhasilan diversifikasi pangan lokal juga semakin tinggi. Semakin rendah harga beras yang dikonsumsi maka keberhasilan diversifikasi pangan lokal semakin tinggi. Semakin baik persepsi terhadap pangan lokal maka keberhasilan diversifikasi pangan lokal juga semakin tinggi. Faktor yang tidak berpengaruh terhadap keberhasilan diversifikasi pangan lokal yaitu umur, tingkat pendidikan, akses media massa, dan motivasi.

\section{Saran}

Untuk meningkatkan keberhasilan dalam diversifikasi pangan lokal sebaiknya dilakukan usaha sebagai berikut :

a. Dengan meningkatkan pendapatan keluarga anggota KWT yang dapat dilakukan dengan menggiatkan diversifikasi usaha pengolahan pangan lokal serta untuk pihak terkait agar aktif memberikan informasi tentang olahan pangan lokal yang potensial dan mempunyai nilai tambah yang tinggi.

b. Dengan meningkatkan keaktifan penyuluhan anggota KWT yang dapat dilakukan dengan usaha dari penyuluh, ketua KWT dan pihak terkait agar menggiatkan anggotanya untuk aktif dalam penyuluhan serta memperbanyak informasi tentang pangan lokal.

c. Dengan meningkatkan persepsi yang positif anggota KWT terhadap pangan lokal yang dapat dilakukan dengan memberikan informasi tentang akses pasar untuk menjual pangan lokal, serta memberikan informasi analisis nilai tambah pengolahan pangan lokal.

\section{DAFTAR PUSTAKA}

Cahyani, G. I. 2008. Analisis Faktor Sosial Ekonomi Keluarga Pedoman Terhadap Keanekaragaman Konsumsi Pangan Berbasis Agribisnis Di Kabupaten Banyumas. Thesis. Program Magister Agribisnis Program Pascasarjana Universitas Diponegoro Semarang.

Fauzi, N. A. I. F. 2012. Pengaruh Motivasi Terhadap Skala Usaha dan Pendapatan Peternak Sapi potong di Eks Karisidenan Pati. Thesis Magister Manajemen agribisnis. Fakultas Pertanian. Universitas Gadjah Mada. Yogyakarta 
Gafur, S. 2009. Motivasi Petani dalam Menerapkan Teknologi Produksi Kakao (Kasus Kecamatan Sirenja Kabupaten Donggala, Sulawesi Tengah). Thesis. Sekolah Pascasarjana. IPB.

Gerungan, W. A. 1983. Psychology Sosial. PT Eresco. Jakarta

Gibson, J., et al. 1996. Organisasi. Jilid 1. Binarupa Aksara. Jakarta

Handoko, M. 1992. Motivasi: Daya Penggerak dan Tingkah Laku. Kanisius. Yogyakarta.

Hariadi, Priyadi, Suratiyah. 1991. Kelompok Wanita Tani di Daerah Lahan Kritis Provinsi Daerah Istimewa Yogyakarta. Pusat Penelitian Kependudukan UGM. Yogyakarta.

Hariadi, S.S. 2011. Dinamika Kelompok. Sekolah Pascasarjana UGM. Yogyakarta

Hasibuan, Malayu S.P. 2005. Manajemen Sumberdaya Manusia, Edisi Revisi. Bumi Aksara. Jakarta.

Jafar, Nurhaedar. 2012. Diversifikasi Konsumsi dan Ketahanan Pangan Masyarakat. Fakultas Kesehatan Masyarakat. Universitas Hasanudin. Makassar

Kartikaningsih, A. 2009. Analisis Faktor-Faktor yang Mempengaruhi Motivasi Petani dalam Berusahatani Tebu. Skripsi. Departemen Agribisnis Instut Pertanian Bogor.

Kasryno, F., M. Gunawan, dan C.A. Rasahan. 1993. Strategi Diversifikasi Produksi Pangan. Prisma, No. 5. Tahun XXII. LP3ES. Jakarta.

Mardikanto, Totok. 1991. Penyuluhan Pembangunan pertanian. Sebelas Maret University Press. Surakarta.
Pelaksanaan Gerakan Percepatan Penganekaragaman Konsumsi Pangan (P2KP) Tahun 2013 Pusat Penganekaragaman Konsumsi dan Keamanan Pangan Badan Ketahanan Pangan Kementerian Pertanian.

Peraturan Menteri Pertanian Nomor 15 Tahun 2013 Tentang Program Peningkatan Diversifikasi dan Ketahanan Pangan Masyarakat Badan Ketahanan Pangan Tahun Anggaran 2013

Peraturan Pemerintah Nomor 22 Tahun 2009 Tentang Percepatan Penganekaragaman
Konsumsi Pangan Berbasis Sumberdaya Lokal.

Peraturan Pemerintah Nomor 68 Tahun 2002 Tentang Ketahanan Pangan

Sari, Novita I. 2013. Konsumsi Beras di Indonesia Masih Tertingi di Dunia. http://m.merdeka.com/uang/konsumsiberas-di-indonesia-masih-tertinggi-didunia.html. Diakses pada 5 Juli 2013

Sayogyo. 1986. Pendekatan Trilogi Pembangunan Sistem Pangan dan Gizi. Rajawali. Jakarta

Soegiharto, S. 2011. Pemberdayaan perempuan di Permukiman Transmigrasi Untuk Percepatan Penganekaragaman Pangan berbasis Pangan Lokal. Jurnal Ketransmigrasian 28 No. 2: 89-102

Sumiati. 2011. Analisis Kelayakan Finansial dan Faktor-Faktor yang Memotivasi Petani dalam Kegiatan Agroforestry. Thesis. Sekolah Pascasarjana Institut Pertanian Bogor.

Suyastiri, Y.P. 2008. Diversifikasi Konsumsi Pangan Pokok Berbasis Potensi Lokal Dalam Mewujudkan Ketahanan Pangan Rumahtangga Pedesaan di Kecamatan Semin Kabupaten Gunungkidul. Jurnal Ekonomi Pembangunan Vol. 13 No.1: 5160.

Umstot, D. 1988. Understanding Organizational Behavior. West Publishing Company. New York

Wastutiningsih, Sri P., Dyah Woro U., Agus S., dan Tri Dyah R. 2012. Kebijakan Pengembangan Pangan Lokal Melalui Penyuluhan Pertanian Menuju Kedaulatan Pangan di Kabupaten Bantul. Jurnal Ilmuilmu Pertanian 16 No. 2: 69-75. 